\title{
Mineralogy and factors controlling charge development of three Oxisols developed from different parent materials.
}

\begin{abstract}
Three Oxisols, developed from serpentinite (Sungai Mas Series), basalt (Kuantan Series) and andesite (Segamat Series), selected to represent the most common Oxisols in Malaysia were sampled and studied. The objectives of this study were: (i) to determine mineralogical composition and factors responsible for changes in point of zero charge $(\mathrm{pH} 0)$ of the variable charge component of three Oxisols; (ii) to use $\mathrm{pH} 0$ values to assess degree of chemical weathering; and (iii) to determine the magnitude of variable charge using corrected backtitration technique. The mineralogical composition was determined by X-ray diffraction analysis (XRD). The $\mathrm{pH} 0$ was determined by potentiometric titration in different electrolyte strengths. The magnitude of variable charge generation as a function of soil $\mathrm{pH}$ was measured using corrected back-titration to allow elimination of charge overestimation caused by solid dissolution and hydrolysis reactions. The results showed that the mineralogical composition were similar (kaolinite, goethite, hematite and gibbsite) between profiles but different in proportion, except for gibbsite which was absent in the andesite-derived soil. The sequential removal of soil organic matter (SOM), iron oxides and SOM together with iron oxides resulted in the changes of $\mathrm{pH} 0$ from 3.9-5.7 to 5.3-6.7, 2.6-3.7 and 3.3-4.5, respectively. These $\mathrm{pH} 0$ changes indicate $\mathrm{SOM}$ and sesquioxides are masking mineral surfaces and are factors responsible for lowering and increasing $\mathrm{pH} 0$ values, respectively. Regression correlation $(\mathrm{R} 2=0.87 * *)$ showed that for every $1 \%$ organic $\mathrm{C}$ may decrease 1.0 unit of $\mathrm{pH} 0$ value. The pH0 values, after SOM removal, are in the order of Sungai Mas $\sim$ Segamat > Kuantan Series. This suggests that the serpentinite and andesite-derived soils have achieved a relatively similar degree of chemical weathering and they are more weathered than the basaltderived soil. The charge measured by corrected back-titration is $1.5-3.8 \mathrm{cmolc} \mathrm{kg}-1$ at $\mathrm{pH}$ 4.5 and increases to $4.2-10.8 \mathrm{cmolc} \mathrm{kg}-1$ at $\mathrm{pH} 6.5$, indicating that the three Oxisols mainly bear variable charge. Charge overestimation resulted from dissolution and hydrolysis reactions during potentiometric titration ranges from 36 to $160 \%$, depending on $\mathrm{pH}$ values (the lower the $\mathrm{pH}$ the higher is the overestimation). Hence, back-titration is a reliable technique to correct charge overestimation when using the traditional potentiometric titration for highly weathered tropical soils.
\end{abstract}

Keyword: Oxisols; Mineralogy; Variable charge; Organic matter; Iron oxides 